ENCYCLOPEDDE Encyclopédie berbère

BERBERE

9 | 1991

9 | Baal - Ben Yasla

\title{
(Al) Bani
}

(Gravures rupestres)

\section{J.-C. Echallier}

\section{(2) OpenEdition}

\section{Journals}

Édition électronique

URL : http://journals.openedition.org/encyclopedieberbere/1280

DOI : 10.4000/encyclopedieberbere.1280

ISSN : 2262-7197

\section{Éditeur}

Peeters Publishers

\section{Édition imprimée}

Date de publication : 1 avril 1991

Pagination : 1333

ISBN : 2-85744-509-1

ISSN : $1015-7344$

\section{Référence électronique}

J.-C. Echallier, «(Al) Bani », Encyclopédie berbère [En ligne], 9 | 1991, document B26, mis en ligne le 01 décembre 2012, consulté le 25 septembre 2020. URL : http://journals.openedition.org/ encyclopedieberbere/1280; DOI : https://doi.org/10.4000/encyclopedieberbere.1280

Ce document a été généré automatiquement le 25 septembre 2020.

(c) Tous droits réservés 


\section{(Al) Bani}

\section{(Gravures rupestres)}

\section{J.-C. Echallier}

1 L'oasis d'Al Bani est située dans le Fenoughil (Touat, Sahara algérien). L'ensemble des gravures est situé sur un groupe de six gros blocs de grès isolés sur le reg à un kilomètre au nord-est du village.

2 Cet ensemble avait été signalé sous le nom de "Abani » par E.-F. Gautier en même temps que d'autres sites, mais à part quelques photographies partielles, aucune représentation ni transcription n'accompagnait le texte.

3 Les gravures se divisent en deux groupes. D'une part des inscriptions libyco-berbères, dont 146 ont pu être relevées et photographiées, d'autre part des figurations diverses : cinq groupes de sandales (dont trois paires), un chameau sellé mais non monté, trois figurations anthropomorphes (deux hommes et une femme?) et trois figurations géométriques non identifiées. La technique est uniformément le piquetage. Les inscriptions apparaissent assez claires sur le fond rocheux qui est presque noir. Une partie des gravures est déjà détruite par l'éclatement des blocs de grès qui se débitent en larges écailles.

4 Cet ensemble de gravures est le plus important, par le nombre des inscriptions, de ceuxrelevés dans le Touat et le Gourara. Les caractéristiques de ces inscriptions, qui présentent des caractères archaïques, les rapprochent des inscriptions anciennes du Maroc. Il semble que tout l'ensemble des gravures du Touat et du Gourara puisse constituer une variante régionale d'alphabet libyco-berbère. 


\section{BIBLIOGRAPHIE}

GAUTIER E.-F., Le Sahara algérien. Mission au Sahara, Paris, A. Colin, 1908, p. 344-346, et pl. XVIII.

INDEX

Mots-clés : Art rupestre, Sahara 